

\title{
PERENCANAAN ULANG TATA LETAK FASILITAS PRODUKSI KERIPIK NANGKA DAN USULAN KESELAMATAN KESEHATAN KERJA DI UMKM DUTA FRUIT CHIPS, KABUPATEN MALANG
}

\section{(Redesign Facility Layout on Production of Jackfruit Chips and Proposal of Health and Safety at UMKM Duta Fruit Chips, Malang Regency)}

\author{
Maulina Pramesti, Heru Santoso Hadi Subagyo, Anisa Aprilia* \\ Jurnal Sosial Ekonomi, Fakultas Pertanian, Universitas Brawijaya \\ Jl. Veteran, Malang 65145 Jawa Timur, Indonesia \\ *Corresponding author: Anisa Aprilia \\ Email: anisa.asa@ub.ac.id
}

Diterima 26 Juni 2019, disetujui 7 November 2019

\begin{abstract}
ABSTRAK
Perencanaan tata letak fasilitas produksi yang sistematis dan kondisi keselamatan kesehatan kerja para karyawan di suatu perusahaan merupakan hal yang sangat penting dilakukan. Namun pada kenyataanya kondisi tata letak UMKM Duta Fruit Chips kurang tertata dengan baik. Hal tersebut dibuktikan dengan letak antar departemen (bagian-bagian produksi) belum berurutan sesuai dengan urutan proses produksinya dan cenderung tidak efektif. Selain itu, faktor kesadaran terhadap keamanan para karyawan dalam proses produksi juga dinilai masih rendah karena saat melakukan proses produksi tidak menggunakan alat pelindung diri (APD) dan banyak karyawan yang sering berpotensi mengalami kecelakaan kerja. Berdasarkan hal tersebut maka dilakukan sebuah penelitian yang bertujuan untuk menghasilkan sebuah perencanaan tata letak usulan. Perencanaan tata letak usulan dilakukan menggunakan Algoritma Blocplan. Algoritma ini dipilih karena dapat menganalisis permasalahan berdasarkan frekuensi perpindahan material dan hubungan derajat kedekatan antar departemendepartemen yang saling berhubungan pada lantai produksi. Tata letak usulan yang dipilih berdasarkan hasil pengolahan Blocplan yang memiliki nilai Rscore mendekati 1. Tata letak yang dipilih yaitu tata letak layout 1 dengan nilai Rscore 0.97. Tata letak tersebut mampu menghasilkan jarak perpindahan aliran bahan sebesar 26,495 meter dan waktu perpindahan bahan sebesar 326,24 detik. Sehingga mampu meminimalkan jarak sebesar 16,45 meter dan waktu sebesar 299,9 detik dari tata letak awal. Selain mampu meminimalkan jarak dan waktu perpindahan aliran bahan tata letak usulan juga mampu meminimalkan jarak antar departemen yang berpotensi menjadi penyebab kecelakaan kerja sehingga dapat meminimalkan tingkat terjadinya kecelakaan kerja.
\end{abstract}

Kata Kunci: Tata Letak Fasilitas Produksi, Keselamatan dan Kesehatan Kerja, Algoritma Blocplan

\section{ABSTRACT}

The planning of facility layout production systematically, and the conditions of work safety and health of employees in a company were needed to be important. However, the condition of the UMKM Duta Fruit Chips layout was not well organized. This was proven by the fact that the location among departments was not sequential according to the production process and tends to be ineffective. It causes the flow of material was contrast and took distance. Beside that, the consciousness factor of 
safety for the employees in the production process was still in low. It was because when carried out the process did not use personal protective equipment and many employees often have a high accidents. Therefore, the writer was interested to conduct a research for producing an alternative layout planning. Alternative layout planning was done using Blocplan Algorithm. This algorithm was chosen because it could analyze problems based on the frequency of material displacement and the relationship of the degree of closeness among related departments on the production floor. The alternative layout was chosen based on the results of Blocplan processing which has a R-score value close to 1 . The layout that chosen was layout 1 with a value of R-score 0.97. It was able to produce material flow movement of 26,495 meters and material transfer time of 326,24 seconds. So that it can minimize the distance was 16,45 meters and a time of 299,9 seconds from the earlier layout. Beside that, either it could minimize the distance and movement time of an alternative layout planning, or minimize the distance among departments which causes a workplace accidental.

Keywords: Facility Layout Production, Work Safety And Health, Blocplan Algorithm

\section{PENDAHULUAN}

Perencanaan tata letak fasilitas produksi merupakan suatu hal yang sangat berpengaruh di dalam dunia industri. Perencanaan tata letak fasilitas produksi dikatakan sangat berpengaruh karena berkaitan dengan tingkat keefisienan dan kesuksesan kinerja industri. Perencanaan tata letak fasilitas produksi merupakan pemilihan secara optimum penempatan mesin-mesin, peralatan pabrik, tempat kerja, dan fasilitas servis bersamasama dengan penentuan bentuk gedung pabriknya (Reksohadiprodho, 2008).

Menurut Handoko (2013) salah satu hal yang terpenting dari tata letak pabrik adalah jarak, waktu, biaya, dan jarak perpindahan material. Tata letak fasilitas produksi menentukan efisiensi produksi dalam jangka panjang. Suatu proses produksi yang memiliki aliran produksi yang panjang membutuhkan pengaturan tata letak dan pemindahan bahan yang efisien sehingga mengurangi back tracking (arus berbalik arah) pada proses produksi. Pengaturan tata letak fasilitas produksi juga akan berguna dalam penentuan penempatan luas mesin maupun fasilitas penunjang produksi lainnya, perpindahan material, penyimpanan material maupun perpindahan pekerja (Wignjosoebroto, 2009).

Pengaturan tata letak fasilitas produksi yang sistematis tidak hanya berfokus pada industri berskala besar dan tingkat pendapatan tinggi namun juga industri berskala kecil hingga menengah. Banyak perusahaan kecil khususnya bergerak dibidang pengolahan hasil pertanian (Agroindustri) juga membutuhkan pengaturan tata letak fasilitas yang baik. UMKM sebagai bentuk usaha kecil yang mengalami perkembangan setiap tahunnya tentu juga membutuhkan perancangan tata letak fasilitas produksi yang baik.

Berdasarkan rilis Radar Malang (2017) menurut Sekretaris UKM Kabupaten Malang, UMKM mikro tingkat pertumbuhannya mencapai 76,4 persen dari sebelumnya 171.440 unit menjadi 302.529 unit. Tentunya UMKM yang berskala kecil hingga menengah merupakan bentuk usaha yang sering mengalami masalah dalam pengaturan tata letak fasilitas produksi. Hal ini disebabkan karena sebagian besar fasilitas dan sarana produksi belum memadai serta tempat produksi yang bersinggungan langsung dengan pemukiman. Menurut Susetyo et al. (2010), sistem material handling (perpindahan aliran bahan) yang kurang sistematis menjadi masalah yang cukup besar dan mengganggu kelancaran terhadap proses produksi sehingga dapat mempengaruhi suatu sistem secara menyeluruh. Akibat dari perencanaan tata letak fasilitas produksi yang tidak sistematis juga menyebabkan aliran proses produksi tidak lancar dan efisien serta ada kemungkinan bahaya yang timbul karena risiko proses produksi.

Bahaya yang timbul dari kegiatan produksi dapat berupa suatu kecelakaan 
ataupun gangguan kesehatan bagi karyawan. Berdasarkan data BPJS Ketenagakerjaan tahun 2017 dalam rilis berita online Republika.co.id terdapat 80.392 kasus kecelakaan kerja UMKM di Jawa Timur. Hal tersebut terjadi karena kurangnya kesadaran dan belum optimalnya pengawasan dan pelaksanaan K3 serta perilaku K3 di tempat kerja.

Fenomena lain yang terjadi yaitu menurut rilis Radar Lampung (Rohlita, 2018) terjadi kebakaran pada UMKM Keripik Singkong yang berlokasi di Telukbetung, Bandar Lampung. Api diduga berasal dari kompor penggorengan keripik singkong yang menyala terlalu besar hingga merembet ke benda-benda di sampingnya. Akibat insiden tersebut, beberapa orang pegawai terkena reruntuhan bangunan dan luka-luka karena terjebak dan sulit untuk keluar. Selain itu, kerugian yang dialami oleh pemilik UMKM mencapai 500 juta.

Berdasarkan hal tersebut penelitian mengenai tata letak fasilitas produksi dan keselamatan kesehatan kerja penting dilakukan. Salah satu studi kasus yang terdapat di salah satu UMKM yaitu adanya pengaturan tata letak antar departemen produksi belum berurutan sesuai dengan urutan proses produksinya dan cenderung tidak efektif. Hal tersebut menyebabkan alur perpindahan bahan berbalik dan menempuh jarak yang cukup jauh. Faktor kesadaran terhadap keamanan para karyawan dalam proses produksi juga dinilai masih rendah karena saat melakukan proses produksi tidak menggunakan alat pelindung diri (APD) dan sering berpotensi mengalami kecelakaan kerja. Hal tersebut juga menjadi perhatian bagi peneliti untuk meneliti tingkat kesadaran karyawan terhadap bahaya yang dapat terjadi.

Berdasarkan pertimbangan tersebut maka dilakukan penelitian mengenai tata letak fasilitas produksi dan keselamatan kesehatan kerja di satu lokasi yang sama untuk melihat kondisi tata letak fasilitas produksi terhadap keselamatan dan kesehatan kerja serta memberikan usulan perencanaan ulang tata letak fasilitas produksi yang sistematis (sesuai dengan urutan proses juga mampu meminimalkan jarak dan waktu proses pemindahan aliran bahan) dan meminimalkan risiko kecelakaan kerja. Hal ini sesuai dengan pernyataan Yuliantoro et al. (2014) bahwa semakin kecil nilai traveling distance (jarak tempuh) yang dihasilkan maka semakin dekat perjalanan pekerja untuk berpindah ke fasilitas proyek ke lain dan semakin kecil nilai safety index (indeks keamanan) maka tingkat kecelakaan yang dialami pekerja yang melalui zona bahaya juga akan semakin kecil. Selain itu, pada penelitian ini juga memberikan usulan keselamatan dan kesehatan kerja secara keseluruhan agar menciptakan kelancaran pada proses produksi dan target perusahaan yang telah ditetapkan dapat tercapai.

Berdasarkan perumusan masalah yang dikaji dalam penelitian ini, dapat dirumuskan pertanyaan penelitian sebagai berikut:

1. Bagaimana kondisi awal tata letak fasilitas produksi keripik nangka UMKM Duta Fruit Chips?

2. Bagaimana usulan tata letak fasilitas produksi keripik nangka UMKM Duta Fruit Chips agar lebih efisien?

3. Bagaimana kondisi tata letak fasilitas produksi terhadap keselamatan dan kesehatan kerja (K3) di area produksi keripik nangka UMKM Duta Fruit Chips?

\section{METODE PENELITIAN}

\section{Pendekatan Penelitian}

Jenis penelitian yang digunakan dalam penelitian ini adalah penelitian kuantitatif dengan pendekatan deskriptif. Analisis kuantitatif digunakan untuk melakukan perhitungan terhadap jarak, luas departemen, jarak antar departemen untuk menganalisis tata letak awal dan menghasilkan tata letak usulan. Selain itu, peneliti menggunakan pendekatan deskriptif karena peneliti ingin mendeskripsikan kondisi keselamatan dan kesehatan kerja pada proses produksi yang diperoleh dengan mengelolah data primer dan sekunder yang didapatkan dari UMKM Duta 
Fruit Chips Kabupaten Malang.

\section{Penentuan Lokasi dan Waktu Penelitian}

Penelitian dilakukan di UMKM Duta

Fruit Chips yang bertempat di Jalan Andong Ampel RT 2 RW 2 Dusun Genitri, Desa Kedungrejo, Kecamatan Pakis, Kabupaten Malang. Metode penentuan lokasi penelitian menggunakan metode purposive sampling yaitu dipilih secara sengaja. Pertimbangan memilih lokasi penelitian ini yang pertama yaitu UMKM ini merupakan salah satu usaha yang bergerak dalam bidang Agribisnis utamanya pengolahan hasil pertanian menjadi pangan. Kedua yaitu adanya permasalahan pada UMKM Duta Fruit Chips mengenai tata letak fasilitas produksi yang memiliki kendala dalam penataan letak antar departemen dan jarak perpindahan bahan baku yang belum optimal. Selain itu, keterjangkauan lokasi penelitian oleh peneliti baik dari segi dana, tenaga dan efisiensi waktu.

\section{Teknik Penentuan Sampel}

Penentuan responden dilakukan secara sengaja (purposive judgement sampling) dengan melakukan wawancara. Penentuan responden menggunakan purposive judgement sampling karena responden dipilih sesuai dengan maksud dan tujuan penelitian. Selain itu juga kesesuaian terhadap pengetahuan terkait bidang yang diteliti. Pihak yang diwawancarai adalah key informant yaitu Ibu Yuyun yang merupakan istri pemilik UMKM sekaligus manajer UMKM, serta seluruh karyawan UMKM Duta Fruit Chips yang berjumlah 10 orang. Key informant dipilih karena responden mengetahui dan memiliki berbagai informasi pokok yang diperlukan dalam penelitian. Responden juga menjawab pertanyaan penunjang penelitian seperti luas area produksi, hubungan kedekatan antar departemen, aliran material, jenis riwayat kecelakaan kerja yang pernah dialami dan hal lain yang menyangkut proses produksi keripik nangka.

Teknik Analisis Data

Algoritma Blocplan. Perencanaan tata letak
UMKM Duta Fruit Chips pada proses produksi Keripik Nangka dilakukan dengan menggunakan software algoritma Blocplan (Block Layout Overview with Layout Planning). Algoritma ini dipilih karena dapat menganalisis permasalahan dari segi kualitatif dan kuantitatif yaitu berdasarkan frekuensi perpindahan material dan hubungan derajat kedekatan antar departemen-departemen yang saling berhubungan pada lantai produksi. Sehingga dengan menggunakan algoritma ini dapat dipertimbangkan layout usulan yang memiliki aliran bahan yang teratur dengan jarak antar operasi yang kecil sehingga menghasilkan momen perpindahan yang minimum (Siregar et al. 2013).

Kelebihan utama software algoritma Blocplan adalah user friendly. Hal ini memungkinkan pengguna untuk mengedit data yang telah dimasukkan, memperbaiki posisi departemen, dan memasukkannya secara manual ke lokasi yang diinginkan. Software ini juga menampilkan tabel layout peringkat yang menunjukkan rel-dist score mentah serta $R$-Score yang dinormalkan setiap layout beserta beberapa informasi lainnya (Heragu,2016).

\section{Metode HIRA (Hazard Identification and}

Risk Assesment). Metode HIRA digunakan untuk melakukan analisis terhadap kondisi keselamtan dan kesehatan kerja. Tujuan dari HIRA adalah untuk memastikan identifikasi bahaya, penilaian risiko dan pengendalian dapat secara efektif mengelola bahaya yang mungkin terjadi dalam tempat kerja (Karthick dan Saravanan, 2014). Langkah yang digunakan untuk melihat sumber bahaya (Hazard) yaitu membuat definisi penyebab Hazard. Kriteria yang digunakan dalam melihat sumber Hazard yaitu dengan melihat kondisi Tata Letak Fasilitas Produksi dan proses produksi di UMKM Duta Fruit Chips. Berikut merupakan kriteria yang digunakan dalam mengidentifikasi bahaya dan penilaian risiko.

\section{Tahap-Tahap Penelitian}

1. Penentuan metode pemecahan masalah 
2. Pengumpulan data, data yang dikumpulkan antara lain:

menggunakan Blocplan

a. Luas Total Fasilitas Produksi

b. Luas Setiap Departemen

c. Jarak Antar Fasilitas

d. Waktu Perpindahan Bahan

e. Jumlah dan Jenis Kecelakaan Kerja yang Pernah Dialami

3. Pengolahan data

a. Pembuatan Activity Relationship Chart

b. Perhitungan Jarak Perpindahan Aliran Bahan

c. Perhitungan Waktu Perpindahan Aliran Bahan

d. Analisa serta Interpretasi Data

e. Mengidentifikasi dan Melakukan Penilaian terhadap Sumber Bahaya dan Risiko saat Bekerja

4. Kesimpulan dan Saran

\section{HASIL DAN PEMBAHASAN}

\section{Deskripsi Perusahaan}

UMKM Duta Fruit Chips merupakan usaha yang bergerak dibidang pengolahan keripik buah khususnya keripik nangka. UMKM ini berlokasi di Jalan Andong Ampel RT 2 RW 2 Dusun Genitri, Desa Kedungrejo, Kecamatan Pakis, Kabupaten Malang. Pada

Tabel 1. Tabel Likelihood

\begin{tabular}{|c|c|c|c|c|}
\hline \multirow{2}{*}{ Level } & \multirow{2}{*}{\multicolumn{2}{|c|}{ Kriteria }} & \multicolumn{2}{|c|}{ Deskripsi } \\
\hline & & & Kualitatif & Semi Kualitatif \\
\hline 1 & Jarang Terjac & & $\begin{array}{l}\text { Dapat dipikirkan terjadi tetapi } \\
\text { tidak hanya keadaan ekstrim }\end{array}$ & $\begin{array}{l}\text { Kurang dari } 2 \text { kali dalam } 10 \\
\text { tahun }\end{array}$ \\
\hline 2 & $\begin{array}{l}\text { Kemungkina } \\
\text { Kecil Terjadi }\end{array}$ & & $\begin{array}{l}\text { Belum terjadi tetapi bisa muncul } \\
\text { pada suatu waktu }\end{array}$ & Terjadi 1 kali per 10 tahun \\
\hline 3 & Mungkin & & $\begin{array}{l}\text { Seharusnya terjadi dan mungkin } \\
\text { pernah terjadi dilokasi }\end{array}$ & $\begin{array}{l}1 \text { kali per } 5 \text { tahun sampai } 1 \\
\text { kali per tahun }\end{array}$ \\
\hline 4 & $\begin{array}{l}\text { Kemungkina } \\
\text { Terjadi }\end{array}$ & & $\begin{array}{l}\text { Terjadi beberapa kali dengan } \\
\text { mudah dalam periode tertentu }\end{array}$ & Lebih dari 1 kali per tahun \\
\hline 5 & $\begin{array}{l}\text { Hampir } \\
\text { Terjadi }\end{array}$ & Pasti & $\begin{array}{l}\text { Dapat terjadi setiap saat dalam } \\
\text { kondisi normal, muncul dalam } \\
\text { keadaan yang paling banyak terjadi }\end{array}$ & Lebih dari 1 kali per bulan \\
\hline
\end{tabular}

Sumber: UNSW Health and Safety, 2008

Tabel 2. Tabel Severity

\begin{tabular}{|c|c|c|c|}
\hline \multirow{2}{*}{ Level } & \multirow{2}{*}{ Uraian } & \multicolumn{2}{|c|}{ Deskripsi } \\
\hline & & Keparahan Cidera & Hari Kerja \\
\hline 1 & Tidak & Dampak yang tidak terjadi sangat tidak & Tidak menyebabkan \\
\hline & Signifikan & mempengaruhi fisik/nyawa pekerja & kehilangan hari kerja \\
\hline 2 & Kecil & $\begin{array}{l}\text { Dampak yang tidak terjadi sangat tidak } \\
\text { mempengaruhi fisik/nyawa pekerja }\end{array}$ & $\begin{array}{l}\text { Masih dapat bekerja pada } \\
\text { shift yang sama }\end{array}$ \\
\hline 3 & Sedang & $\begin{array}{l}\text { Dampak yang tidak terjadi sangat tidak } \\
\text { mempengaruhi fisik/nyawa pekerja }\end{array}$ & $\begin{array}{l}\text { Kehilangan hari kerja } \\
\text { dibawah } 3 \text { hari }\end{array}$ \\
\hline 4 & Berat & $\begin{array}{l}\text { Dampak yang tidak terjadi sangat tidak } \\
\text { mempengaruhi fisik/nyawa pekerja }\end{array}$ & $\begin{array}{l}\text { Kehilangan hari kerja } 3 \text { hari } \\
\text { atau lebih }\end{array}$ \\
\hline 5 & Bencana & $\begin{array}{l}\text { Dampak yang tidak terjadi sangat tidak } \\
\text { mempengaruhi fisik/nyawa pekerja }\end{array}$ & $\begin{array}{l}\text { Kehilangan hari kerja } \\
\text { selamanya }\end{array}$ \\
\hline
\end{tabular}

Sumber: UNSW Health and Safety, 2008 
tahun 2014 UMKM ini mulai beroperasi dibawah pimpinan Bapak Lukman Hakim sebagai pemilik dan Ibu Yuyun sebagai manajer di UMKM tersebut. UMKM ini memiliki luas sebesar $144,80 \mathrm{~m}^{2}$. Proses produksi yang dilakukan sebagian besar menggunakan tenaga manusia, hanya saja saat proses penggorengan telah menggunakan mesin vacuum frying.

Setiap harinya UMKM ini hanya mampu memproduksi $\pm 50 \mathrm{~kg}$ keripik buah dengan mengisi kapasitas mesin penggorengan masing-masing $35 \mathrm{~kg}$ buah kupas. Padahal kapasitas mesin yang dimiliki masing-masing $35 \mathrm{~kg}$ dan $50 \mathrm{~kg}$. Hal ini terjadi karena ada beberapa kendala berupa waktu dan tenaga kerja. Selain itu, para karyawan juga sering mengalami beberapa jenis kecelakaan kerja yang disebabkan oleh kondisi tata letak yang belum sesuai dengan pola aliran produksi. Jumlah karyawan saat ini sebanyak 10 orang yang terdiri dari 6 berjenis kelamin perempuan dan 4 orang laki-laki.

Sistem pendistribusian produk keripik tidak dilakukan setiap hari hanya $3-4$ hari sekali. Namun, jika permintaan meningkat seperti saat hari raya maupun liburan pengiriman dilakukan setiap hari. Selain memproduksi keripik nangka, UMKM ini juga memproduksi keripik buah lain seperti Apel dan Salak. Sebagian besar hasil produksi UMKM Duta Fruit Chips dikirimkan kepada agen-agen penjual oleh-oleh untuk dikemas sendiri oleh agen tersebut. Pelanggan tetap UMKM Duta Fruit Chips sebagian besar berlokasi di Kabupaten Malang yaitu daerah Tumpang dan Singosari. Namun, beberapa pelanggan tetap juga terdapat di daerah Kota Malang dan Kota Batu.

\section{Identifikasi Tata Letak Awal}

Pola aliran bahan dalam proses pembuatan keripik nangka di UMKM Duta Fruit Chips belum memiliki pola aliran bahan yang berurutan secara baik. Terdapat empat departemen yang belum berurutan sesuai dengan alur proses produksinya yaitu pada bagian penyimpanan bahan baku (departemen A) dan pengupasan (departemen B), bagian pengupasan (departemen B) dan bagian pencucian dan perendaman (departemen C), bagian pembekuan (departemen D) dan bagian penggorengan (departemen E). Hal tersebut menyebabkan terjadinya aliran bahan yang berbaik arah (back tracking). Selain itu, UMKM Duta Fruit Chips memang tidak memiliki perencanaan tata letak produksi yang sistematis, sehingga memiliki luas area produksi yang tidak begitu luas, banyak karyawan yang berlalu lalang melakukan pemindahan bahan yang hampir saling bertabrakan. Berikut merupakan kondisi tata

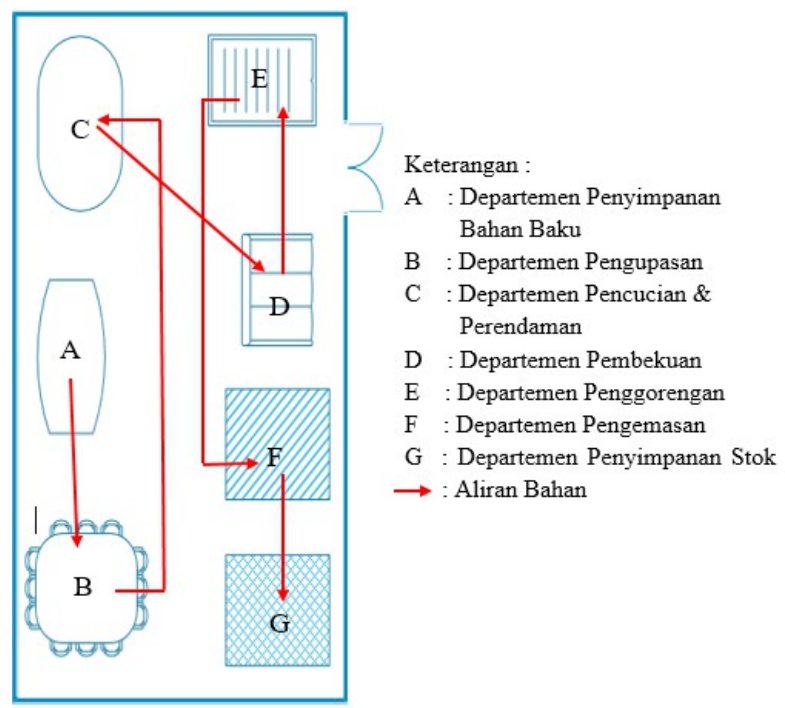

Ilustrasi 1. Kondisi Tata Letak Awal

letak awal fasilitas produksi UMKM Duta Fruit Chips dapat dilihat pada Ilustrasi 1.

Tabel 3 menyajikan titik koordinat pada setiap departemen produksi dalam proses Tabel 3. Koordinat Departemen Produksi pada Kondisi Tata Letak Awal

\begin{tabular}{cc}
\hline Departemen & Titik Koorditas $(\mathrm{x}, \mathrm{y})$ \\
\hline A & $(5.525,17.73)$ \\
B & $(5.965,12.5)$ \\
C & $(5.785,23)$ \\
D & $(11.48,19.24)$ \\
E & $(11.05,23.975)$ \\
F & $(11.05,15.74)$ \\
G & $(11.05,12)$ \\
\hline
\end{tabular}


Tabel 4. Data Luas Departemen

\begin{tabular}{|c|c|c|c|}
\hline Kode & Area & Ukuran (cm) & $\begin{array}{l}\text { Total Luas } \\
\left(\mathrm{cm}^{2}\right)\end{array}$ \\
\hline A & $\begin{array}{l}\text { Departemen } \\
\text { Penyimpanan } \\
\text { Bahan Baku }\end{array}$ & $195 \times 346$ & 67.470 \\
\hline B & $\begin{array}{l}\text { Departemen } \\
\text { Pengupasan }\end{array}$ & $293 \times 247$ & 72.371 \\
\hline $\mathrm{C}$ & $\begin{array}{l}\text { Departemen } \\
\text { Pencucian dan } \\
\text { Perendaman }\end{array}$ & $243 \times 395$ & 95.985 \\
\hline $\mathrm{D}$ & $\begin{array}{l}\text { Departemen } \\
\text { Pembekuan }\end{array}$ & $252 \times 204$ & 51.408 \\
\hline $\mathrm{E}$ & $\begin{array}{l}\text { Departemen } \\
\text { Penggorengan }\end{array}$ & $205 \times 310$ & 63.550 \\
\hline $\mathrm{F}$ & $\begin{array}{l}\text { Departemen } \\
\text { Pengemasan }\end{array}$ & $250 \times 300$ & 75.000 \\
\hline G & $\begin{array}{l}\text { Departemen } \\
\text { Penyimpanan } \\
\text { Stok }\end{array}$ & $250 \times 300$ & 75.000 \\
\hline
\end{tabular}

Sumber: Data Primer, 2019 (diolah)

Tabel 5. Simbol Activity Relationship Chart (ARC)

\begin{tabular}{cclc}
\hline Kode & \multicolumn{1}{c}{ Makna } & \multicolumn{2}{c}{ Keterangan } \\
\hline A & Absolutely necessary & $\begin{array}{l}\text { Mutlak } \\
\text { didekatkan }\end{array}$ & perlu \\
& & penting \\
E & Especially Important & $\begin{array}{l}\text { Sangat } \\
\text { didekatkan }\end{array}$ \\
& & Penting didekatkan \\
I & Important & Netral & \\
O & Ordinary & Tidak penting untuk \\
U & Unimportant & berdekatan & \\
& & Tidak dikehendaki \\
X & Undesirable & Tile
\end{tabular}

Sumber: Wignjosoebroto, 2009

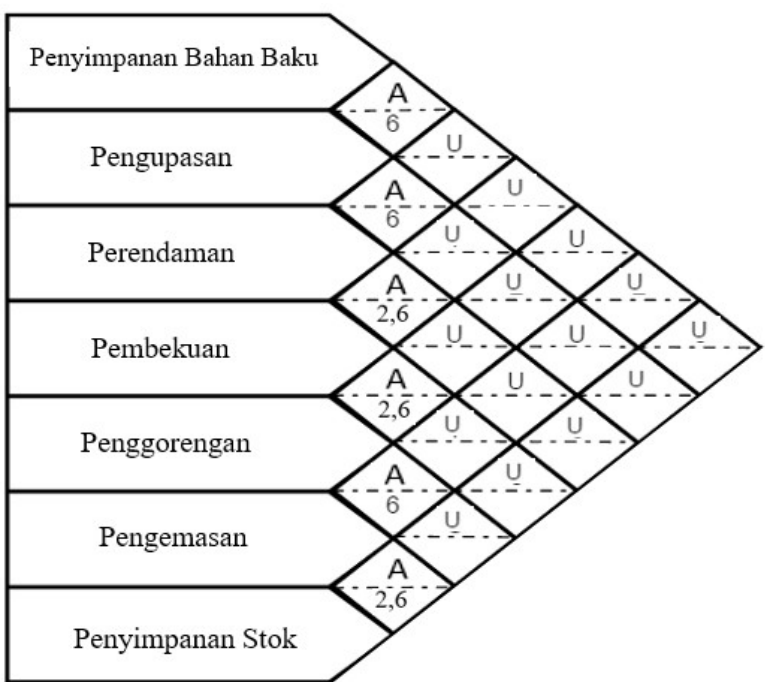

Ilustrasi 2. ARC Pembuatan Keripik Nangka pembuatan keripik nangka di UMKM Duta Fruit Chips.

Tabel 4 menyajikan luas masing-masing departemen proses produksi. Luas keseluruhan total fasilitas produksi sebesar $144,80 \mathrm{~m}^{2}$. Terdapat 7 departemen bagian kerja dalam melakukan proses produksi. Setelah melakukan identifikasi terhadap titik koordinat masing - masing departemen dan luas masing - masing departemen dilakukan pembuatan Activity Relationship Chart (ARC).

Activity Relationship Chart (ARC) atau yang biasa disebut dengan peta keterkaitan memiliki fungsi menggambarkan hubungan antar departemen dari aktivitas-aktivitas tertentu, sehingga dapat ditentukan aktivitas yang harus berdekatan dan aktivitas yang harus berjauhan dalam suatu perancangan tata letak fasilitas. Penentuan yang dilakukan dalam pembuatan peta keterkaitan ini menggunakan simbol. Simbol yang digunakan yaitu A, E, I, O, U, X. Keterangan mengenai simbol hubungan keterkaitan disajikan pada Tabel 5 .

Ilustrasi 2 menampilkan Activity Relationship Chart (ARC) pada UMKM Duta Fruit Chips. Berdasarkan Activity Relationship Chart (ARC) diatas, dapat dilihat bahwa diberikan kode yaitu A dan U. Kode A diberikan ketika departemen tersebut mutlak perlu didekatkan karena adanya aliran proses produksi yang berurutan. Kode U diberikan ketika departemen tersebut tidak penting untuk didekatkan karena dalam aliran proses produksi tidak berurutan dan tidak ada keterkaitan langsung antar departemen tersebut.

\section{Jarak Perpindahan Aliran Bahan Tata Letak Awal}

Jarak perpindahan aliran bahan (material handling) merupakan jarak yang ditempuh untuk memindahkan material atau bahan baku dari satu departemen ke departemen lainnya. Pengukuran jarak perpindahan aliran bahan menggunakan metode pengukuran jarak rectilinear. Metode pengukuran jarak 
Tabel 6. Jarak Perpindahan Material Tata Letak Awal

\begin{tabular}{cccccc}
\hline $\begin{array}{c}\text { Departemen } \\
\text { Awal }\end{array}$ & $\begin{array}{c}\text { Departemen } \\
\text { Tujuan }\end{array}$ & $\begin{array}{c}\text { Total Jarak } \\
\text { (meter) }\end{array}$ & Frekuensi & $\begin{array}{c}\text { Total Waktu per } \\
\text { meter (detik) }\end{array}$ & $\begin{array}{c}\text { Total Waktu } \\
\text { (detik) }\end{array}$ \\
\hline A & B & 11,340 & 2 & 1,94 & 21,99 \\
B & C & 32,040 & 3 & 1,96 & 62,79 \\
C & D & 18,910 & 2 & 1,95 & 36,87 \\
D & E & 5,165 & 1 & 1,93 & 9,96 \\
E & F & 8,675 & 1 & 2,07 & 17,95 \\
F & G & 3,750 & 1 & 1,86 & 6,97 \\
\hline TOTAL & & & & & 156,535 \\
\hline
\end{tabular}

Sumber : Data Primer, 2019 (diolah)

Tabel 7. Waktu Pemindahan Bahan Tata Letak Awal

\begin{tabular}{cccccc}
\hline $\begin{array}{c}\text { Departemen } \\
\text { Awal }\end{array}$ & $\begin{array}{c}\text { Departemen } \\
\text { Tujuan }\end{array}$ & $\begin{array}{c}\text { Total Jarak } \\
\text { (meter) }\end{array}$ & Frekuensi & $\begin{array}{c}\text { Total Waktu per } \\
\text { meter (detik) }\end{array}$ & $\begin{array}{c}\text { Total Waktu } \\
\text { (detik) }\end{array}$ \\
\hline A & B & 11,340 & 2 & 1,94 & 21,99 \\
B & C & 32,040 & 3 & 1,96 & 62,79 \\
C & D & 18,910 & 2 & 1,95 & 36,87 \\
D & E & 5,165 & 1 & 1,93 & 9,96 \\
E & F & 8,675 & 1 & 2,07 & 17,95 \\
F & G & 3,750 & 1 & 1,86 & 6,97 \\
\hline TOTAL & & & & & 156,535 \\
\hline
\end{tabular}

Sumber : Data Primer, 2019 (diolah)

rectilinear dapat diaplikasikan dengan cara mengukur jarak perpindahan material yang tegak lurus berdasarkan titik koordinat masing-masing departemen. Metode ini dipilih karena kondisi tata letak di UMKM Duta Fruit Chips tidak beraturan sehingga lebih mudah dengan menggunakan titik koordinat dan mendekati aktual. Berikut merupakan hasil pengukuran jarak material handling antar departemen pada kondisi tata letak awal.

Berdasarkan Tabel 6. dapat diketahui pada kondisi tata letak awal, jarak perpindahan aliran material total sebesar 42,945 meter. Jarak perpindahan terbesar terjadi pada perpindahan dari departemen pengupasan menuju departemen pencucian dan perendaman. Hal ini dikarenakan kondisi departemen pengupasan dengan departemen pencucian dan perendaman tidak sesuai dengan urutan proses produksi serta adanya aliran berbalik arah (back tracking).

\section{Waktu Proses Pemindahan Bahan Tata Letak Awal}

Waktu proses pemindahan bahan merupakan hal yang penting dalam suatu proses produksi. Adapun waktu yang dibutuhkan dalam proses pemindahan bahan pada tata letak awal dalam satu kali produksi dapat dilihat pada Tabel 7.

Berdasarkan Tabel 7. dapat diketahui total waktu yang dibutuhkan dalam proses pemindahan bahan pada tata letak awal sebesar 156,535 detik dalam 1 kali proses produksi atau satu kali penggorengan. Maka jika 1 hari terdapat 4 kali proses produksi maka total waktu yang dibutuhkan pada proses pemindahan bahan dalam satu hari sebesar 626,14 detik.

\section{Perencanaan Tata Letak Usulan Menggunakan Algoritma Blocplan}

Perancangan tata letak usulan di UMKM Duta Fruit Chips menggunakan metode Blocplan. Perancangan ulang tata letak dilakukan pada fasilitas produksi pembuatan 


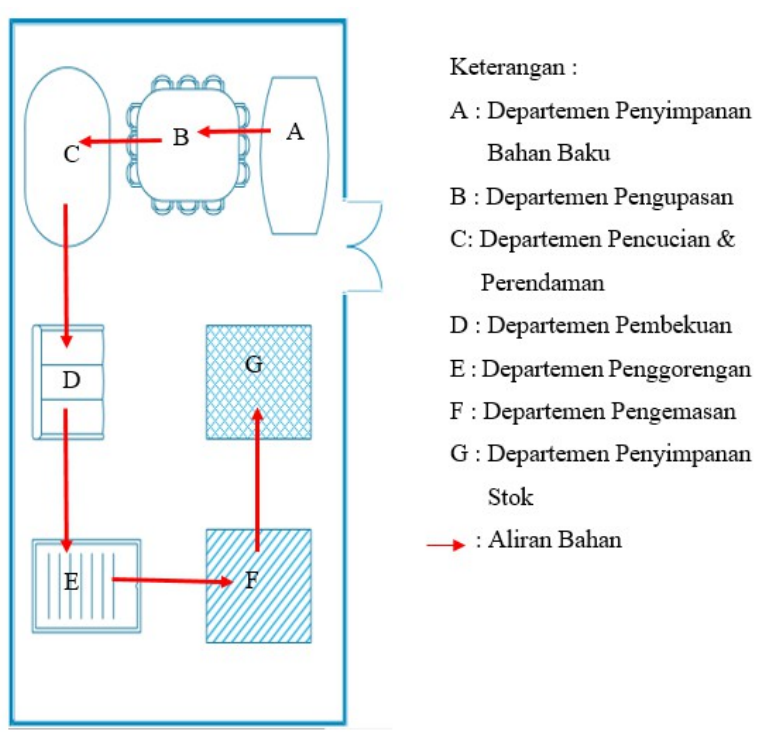

Ilustrasi 3. Kondisi Tata Letak Usulan

keripik nangka mulai dari departemen penyimpanan bahan baku (Departemen A) hingga departemen penyimpanan stok atau porduk jadi (Departemen G). Terdapat total 7 departemen yang digunakan sebagai data masukan pada algoritma Blocplan. Hasil perencanaan ulang tata letak usulan menggunakan Algoritma Blocplan disajikan pada Ilustrasi 3.

Berdasarkan layout usulan pada Ilustrasi 3, maka koordinat departemen yang baru disajikan pada Tabel 8.

Tabel 8. Koordinat Departemen Layout Usulan

\begin{tabular}{cc}
\hline Departemen & Titik Koorditas $(\mathrm{x}, \mathrm{y})$ \\
\hline A & $(12.025,22.5)$ \\
B & $(8.965,22.735)$ \\
C & $(5.5,22.475)$ \\
D & $(5.52,17.5)$ \\
E & $(6.05,13)$ \\
F & $(11,13)$ \\
G & $(11,17.5)$ \\
\hline
\end{tabular}

Sumber: Data Primer, 2019 (diolah)

Perencanaan layout usulan berdasarkan hasil dari output Blocplan yang memiliki Rscore tertinggi yaitu layout 1 dengan nilai 0,97 . Perencanaan layout usulan dilakukan tanpa merubah luas setiap departemen namun, merubah posisi beberapa departemen sesuai dengan proses produksinya. Hal ini dilakukan agar dapat memperpendek jarak tempuh perpindahan aliran bahan.

Pola aliran bahan tata letak usulan dalam proses produksi pembuatan keripik nangka memiliki pola aliran berbentuk $O$. Hal ini dicirikan dengan akhir dari proses produksi akan berada pada lokasi yang sama dengan awal proses masuknya material (satu pintu). Hal tersebut sesuai dengan pernyataan Purnomo (2004) bahwa pola aliran bentuk O digunakan jika keluar masuknya material dan produk pada satu tempat/ satu pintu, kondisi ini memudahkan dalam pengawasan keluar masuknya barang.

\section{Jarak Perpindahan Aliran Bahan Tata Letak Usulan}

Metode yang digunakan dalam perhitungan jarak antar departemen pada tata letak usulan, sama dengan metode yang digunakan pada tata letak awal yaitu menggunakan metode rectilinear. Berdasarkan hasil perhitungan jarak aliran bahan pada tata letak usulan diketahui sebesar 26,495 meter sedangkan pada tata letak awal sebesar 42,945 meter. Perencanaan tata letak usulan dapat meminimalkan jarak perpindahan aliran bahan sebesar 16,45 meter. Jarak perpindahan aliran bahan pada tata letak usulan dapat dilihat pada Tabel 9.

Tabel 9. Jarak Perpindahan Material Tata Letak Usulan

\begin{tabular}{|c|c|c|c|}
\hline Departemen Awal & $\begin{array}{c}\text { Departemen } \\
\text { Tujuan }\end{array}$ & Kode & $\begin{array}{c}\text { Jarak } \\
\text { (meter) }\end{array}$ \\
\hline $\begin{array}{l}\text { Penyimpanan } \\
\text { bahan baku }\end{array}$ & Pengupasan & A-B & 3,295 \\
\hline Pengupasan & $\begin{array}{l}\text { Pencucian dan } \\
\text { perendaman }\end{array}$ & $\mathrm{B}-\mathrm{C}$ & 3,725 \\
\hline $\begin{array}{l}\text { Pencucian dan } \\
\text { perendaman }\end{array}$ & Pembekuan & C-D & 4,995 \\
\hline Pembekuan & Penggorengan & D-E & 5,030 \\
\hline Penggorengan & Pengemasan & E-F & 4,950 \\
\hline \multirow[t]{2}{*}{ Pengemasan } & Penyimpanan stok & $\mathrm{F}-\mathrm{G}$ & 4,500 \\
\hline & TOTAL & & 26,495 \\
\hline
\end{tabular}

Sumber: Data Primer, 2019 (diolah) 
Tabel 10. Waktu Proses Pemindahan Bahan Tata Letak Usulan

\begin{tabular}{cccccc}
\hline $\begin{array}{c}\text { Departemen } \\
\text { Awal }\end{array}$ & $\begin{array}{c}\text { Departemen } \\
\text { Tujuan }\end{array}$ & $\begin{array}{c}\text { Total Jarak } \\
\text { (meter) }\end{array}$ & Frekuensi & $\begin{array}{c}\text { Total Waktu per } \\
\text { meter (detik) }\end{array}$ & $\begin{array}{c}\text { Total Waktu } \\
\text { (detik) }\end{array}$ \\
\hline A & B & 6,590 & 2 & 1,94 & 12,78 \\
B & C & 11,175 & 3 & 1,96 & 21,90 \\
C & D & 9,990 & 2 & 1,95 & 19,48 \\
D & E & 5,030 & 1 & 1,93 & 9,71 \\
E & F & 4,950 & 1 & 2,07 & 10,25 \\
F & G & 4,500 & 1 & 1,86 & 7,44 \\
\hline TOTAL & & & & & 81,56 \\
\hline
\end{tabular}

Sumber : Data Primer, 2019 (diolah)

\section{Waktu Proses Pemindahan Bahan Tata Letak Usulan}

Berdasarkan hasil perhitungan waktu proses pemindahan pada tata letak awal dalam satu hari (4 kali produksi) diketahui sebesar 626,14 detik sedangkan pada tata letak usulan sebesar 326,24 detik. Perencanaan tata letak usulan dapat meminimalkan waktu proses pemindahan bahan sebesar 299,9 detik. Menurut Wignjosoebroto (2009) proses pemindahan bahan dari operasi ke operasi lain, waktu dapat dihemat dengan cara mengurangi jarak perpindahan tersebut. Jarak perpindahan aliran bahan pada tata letak usulan dalam 1 kali proses produksi dapat dilihat pada Tabel 10 .

\section{Kondisi Keselamatan dan Kesehatan Kerja}

Data mengenai keselamatan dan kesehatan kerja diperoleh dengan mencari sumber data primer. Data primer didapatkan dengan cara observasi langsung di area poduksi UMKM Duta Fruit Chips dengan mengamati dan mendokumentasikan hazard yang telah ditemukan dilapangan. Selain itu juga dengan mewawancarai semua pekerja mengenai kecelakaan apa saja yang pernah dialami mereka selama bekerja di UMKM Duta Fruit Chips. Tabel 11. menampilkan temuan hazard serta penilaian risiko yang mana data berasal dari rekap riwayat kecelakaan pekerja tahun 2016 -2018 dan penilaian dilakukan berdasarkan tabel kriteria likelihood dan consequences serta matriks risiko.

Berdasarkan Tabel 11. dapat diketahui bahwa terdapat 5 temuan hazard secara keseluruhan dan 3 temuan yang tergolong ekstrim dan tinggi. Masih banyaknya kejadian kecelakaan kerja yang terjadi di lokasi produksi disebabkan karena rendahnya tingkat kesadaran terhadap keselamatan kerja dan beranggapan bahwa kecelakaan yang terjadi merupakan hal yang dapat ditoleransi. Selain itu, alat P3K (Pertolongan Pertama pada Kecelakaan) juga tidak tersedia secara lengkap hanya terdapat minyak kayu putih dan plester luka saja. Sehingga apabila kejadian tersebut sering terjadi kembali hanya diatasi dengan obat-obatan seadanya sudah dirasa cukup.

Tiga temuan hazard yang tergolong tingkat risiko ekstrim dan tinggi tersebut terdapat pada 4 departemen produksi. Tingkat risiko ekstrim terdapat pada jalur lintasan antara departemen perendaman dengan departemen pembekuan yang disebabkan kondisi lantai licin. Sedangkan temuan hazard pada departemen pengupasan karena pekerja tidak menggunakan pelindung tangan (APD) dan kondisi lantai licin akibat tetesan minyak pada departemen penggorengan tergolong tingkat risiko tinggi.

Selain itu, identifikasi uraian jenis hazard juga dilakukan analisis terhadap pengaruh tata letak fasilitas produksi yang ada. Berdasarkan hasil analisis terdapat satu uraian temuan jenis hazard yang dipengaruhi oleh tata letak fasilitas produksi yang ada yaitu kondisi jalur perpindahan aliran bahan yang licin. Kondisi tersebut disebabkan jarak perpindahan aliran bahan dari departemen perendaman menuju departemen pembekuan terlalu jauh. Jarak yang terlalu jauh 
Tabel 11. Temuan Hazard dan Penilaian Risiko

\begin{tabular}{|c|c|c|c|c|c|c|c|c|c|}
\hline Departemen & $\begin{array}{c}\text { Uraian } \\
\text { Temuan } \\
\text { Hazard }\end{array}$ & Foto & Risiko & $\begin{array}{l}\text { Sumber } \\
\text { Hazard }\end{array}$ & $\begin{array}{c}\mathbf{L} \\
\text { (likelihood) }\end{array}$ & $\begin{array}{c}\mathrm{C} \\
\text { (consequences) }\end{array}$ & Skala & $\begin{array}{c}\text { Kategori } \\
\text { Risiko }\end{array}$ & $\begin{array}{c}\text { Pengaruh } \\
\text { Tata } \\
\text { Letak } \\
\end{array}$ \\
\hline $\begin{array}{l}\text { Penyimpanan } \\
\text { bahan baku }\end{array}$ & $\begin{array}{l}\text { Pekerja } \\
\text { tidak } \\
\text { mengguna - } \\
\text { kan } \\
\text { pelindung } \\
\text { tangan } \\
\text { (APD) saat } \\
\text { pemindahan } \\
\text { bahan baku }\end{array}$ & & $\begin{array}{l}\text { Tergores } \\
\text { kulit } \\
\text { nangka } \\
\text { yang } \\
\text { tajam }\end{array}$ & $\begin{array}{l}\text { Sikap } \\
\text { pekerja }\end{array}$ & 3 & 2 & 6 & $\begin{array}{c}\mathrm{M} \\
\text { (Sedang) }\end{array}$ & 1 \\
\hline Pengupasan & $\begin{array}{l}\text { Pekerja } \\
\text { tidak } \\
\text { mengguna- } \\
\text { kan } \\
\text { pelindung } \\
\text { tangan } \\
\text { (APD) saat } \\
\text { melakukan } \\
\text { pengupasan }\end{array}$ & & $\begin{array}{l}\text { Tergores } \\
\text { pisau } \\
\text { pemotong }\end{array}$ & $\begin{array}{l}\text { Sikap } \\
\text { pekerja }\end{array}$ & 4 & 3 & 12 & $\begin{array}{c}\mathrm{H} \\
\text { (Tinggi) }\end{array}$ & 1 \\
\hline Penggorengan & $\begin{array}{l}\text { Kondisi } \\
\text { lantai } \\
\text { sedikit } \\
\text { licin terkena } \\
\text { tetesan } \\
\text { minyak }\end{array}$ & & $\begin{array}{l}\text { Terpleset } \\
\text { lantai } \\
\text { licin }\end{array}$ & & 3 & 3 & $\begin{array}{l}9 \\
\\
\text { Activ }\end{array}$ & $\begin{array}{c}\mathrm{H} \\
\text { (Tinggi) } \\
\\
\\
\\
\text { ate Windows }\end{array}$ & 5 \\
\hline $\begin{array}{l}\text { Perendaman - } \\
\text { pembekuan }\end{array}$ & $\begin{array}{l}\text { Kondisi } \\
\text { lantai } \\
\text { licin terkena } \\
\text { tetesan air }\end{array}$ & & $\begin{array}{l}\text { Terpleset } \\
\text { lantai } \\
\text { licin }\end{array}$ & $\begin{array}{l}\text { Lantai } \\
\text { licin }\end{array}$ & 4 & 4 & 16 & $\begin{array}{c}\text { E } \\
(\text { Ekstrim) }\end{array}$ & 2 \\
\hline Pengemasan & $\begin{array}{l}\text { Pekerja } \\
\text { tidak } \\
\text { mengguna- } \\
\text { kan } \\
\text { pelindung } \\
\text { tangan saat } \\
\text { melakukan } \\
\text { pengemasan }\end{array}$ & & $\begin{array}{l}\text { Terkena } \\
\text { panas } \\
\text { sealer }\end{array}$ & $\begin{array}{l}\text { Sikap } \\
\text { pekerja }\end{array}$ & 3 & 2 & 6 & $\begin{array}{c}\mathrm{M} \\
\text { (Sedang) }\end{array}$ & 1 \\
\hline
\end{tabular}

menyebabkan banyaknya air sisa perendaman yang masih menempel pada bahan menetes disepanjang jalur sehingga jalur perpindahan bahan menjadi licin dan banyak karyawan yang mengalami kecelakaan kerja (terpleset). Rencana perbaikan yang diberikan berdasarkan sumber bahaya disajikan pada Tabel 12.
Selain usulan perbaikan terhadap sumber hazard yang memiliki level risiko tinggi dan esktrim, di UMKM Duta Fruit Chip juga masih ditemukan beberapa penyimpangan yang kurang sesuai dengan standar seperti penyediaan alat $\mathrm{P} 3 \mathrm{~K}$ dan alat pelindung diri pada anggota tubuh tertentu. Berikut merupakan standar yang harus dilakukan bagi pekerja industri. 
Tabel 12. Rencana Perbaikan yang Diberikan

\begin{tabular}{|c|c|c|c|c|c|}
\hline No & $\begin{array}{l}\text { Sumber } \\
\text { Hazard }\end{array}$ & Deviation & Cause & Consequences & Action \\
\hline 1. & sikap pekerja & $\begin{array}{l}\text { 1. Pekerja } \\
\text { bertindak tidak } \\
\text { aman } \\
\text { 2. Pekerja tidak } \\
\text { menggunakan } \\
\text { APD (Safety } \\
\text { gloves, masker, } \\
\text { safety shoes) }\end{array}$ & $\begin{array}{l}\text { 1. Kurang } \\
\text { disiplinnya } \\
\text { sikap pekerja } \\
\text { 2. Rendahnya } \\
\text { kesadaran dan } \\
\text { pengetahuan } \\
\text { akan } \\
\text { keselamatan } \\
\text { kerja } \\
\text { 3. Kurangnya } \\
\text { sikap tegas dari } \\
\text { pihak } \\
\text { manajemen } \\
\text { 4. Penyediaan } \\
\text { APD yang } \\
\text { sangat minim } \\
\text { sekali }\end{array}$ & $\begin{array}{l}\text { 1. Anggota tubuh } \\
\text { terluka } \\
\text { 2. Tertusuk } \\
\text { permukaan } \\
\text { tajam }\end{array}$ & $\begin{array}{l}\text { 1. Membuat } \\
\text { prosedur kerja } \\
\text { yang baik } \\
\text { 2. Melakukan } \\
\text { pelatihan K3 } \\
\text { kepada para } \\
\text { pekerja } \\
\text { 3. Menyediakan } \\
\text { APD dengan } \\
\text { cukup }\end{array}$ \\
\hline 2. & Lantai Basah & $\begin{array}{l}\text { Terdapat } \\
\text { banyak } \\
\text { genangan air } \\
\text { dan tetesan } \\
\text { minyak }\end{array}$ & $\begin{array}{l}\text { 1. Jarak } \\
\text { perpindahan } \\
\text { bahan yang } \\
\text { terlalu jauh } \\
\text { sehingga } \\
\text { menetes lebih } \\
\text { banyak } \\
\text { 2. Lantai yang } \\
\text { basah tidak } \\
\text { segera } \\
\text { dibersihkan }\end{array}$ & $\begin{array}{l}\text { Terpeleset } \\
\text { genangan air } \\
\text { atau tetesan } \\
\text { minyak }\end{array}$ & $\begin{array}{l}\text { 1. Segera } \\
\text { mengeringkan } \\
\text { lantai yang } \\
\text { basah } \\
\text { 2. Membuat } \\
\text { saluran } \\
\text { pembuangan } \\
\text { air yang } \\
\text { tergenang } \\
\text { 3. Melakukan } \\
\text { perbaikan } \\
\text { kondisi tata } \\
\text { letak }\end{array}$ \\
\hline
\end{tabular}

1. Menggunakan Penutup Kepala

Penutup kepala berfungsi untuk menghindari kontaminasi produk akibat rambut pekerja yang jatuh. Selain melindungi produk, penutup kepala juga difungsikan untuk melindungi kepala dari debu ataupun bahaya terjeratnya rambut pada mesin-mesin berputar. Menggunakan penutup kepala, umumnya rambut akan lebih rapi karena berada didalam penutup kepala tersebut.

2. Menggunakan Penutup Hidung dan Mulut Penutup hidung dan mulut atau yang biasa dikenal masker berfungsi untuk melindungi olahan pangan dari pencemaran bakteri yang tidak diinginkan. Melindungi dari bersin dan penularan penyakit atau bakteri sehingga makanan yang diolah tetap higienis. Selain itu dapat mencegah terjadinya dampak negatif yang dikarenakan oleh debu yang bercampur dengan kumankuman yang berada di sekitar kita yang terhirup oleh hidung maupun mulut.

3. Menggunakan Sarung Tangan

Menggunakan sarung tangan kerja untuk melindungi tangan pada saat bekerja di tempat atau situasi tertentu 
yang berpotensi untuk mengakibatkan cedera tangan untuk melindungi seluruh bagian tangan hingga ke jari-jari selama melakukan pekerjaan tertentu. Misalnya untuk melindungi tangan dari api, suhu panas dan dingin, radiasi, arus listrik, benturan dan pukulan, tergores benda tajam/kasar.

4. Menggunakan Baju Khusus dan Apron

Pakaian khusus yang digunakan pekerja pengolahan makanan biasanya dibuat dari bahan yang menyerap keringat dan berlengan panjang. Pada bagian dada dibuat berlapis dua. Tujuannya adalah untuk melindungi bagian dada dari panas api dan makanan yang menyirami tubuh dan melindungi tangan dari barang panas. Selain itu juga terdapat apron untuk melindungi tubuh bagian bawah dari cairan seperti air, getah, atau cairan panas yang mungkin menyiram.

5. Menggunakan Sepatu Khusus (Safety Shoes)

Sepatu khusus dapat mengurangi risiko kecelakaan kerja fatal seperti kejatuhan benda-benda berat. Safety shoes ini memiliki kemampuan yang cukup kuat dalam menahan berat, hingga risiko patah tulang atau masalah yang lain dapat diminimalisir. Sepatu safety terbuat dari bahan karet yang didesain sedemikian rupa, hingga sepatu ini dapat di andalkan pada permukaan licin.

Selain usulan terhadap perbaikan standar pengadaan dan pemakaian alat pelindung tubuh, penyediaan alat P3K (Pertolongan Pertama pada Kecelakaan) juga sangat diperlukan. P3K dapat dijadikan sebagai pertolongan pertama saat terjadi kecelakaan seperti menghentikan pendarahan pada kepala, tangan, atau kaki Standar penyediaan alat P3K tersebut meliputi:
a) Perban.
b) Kain kasa gulung dan steril.
c) Sarung tangan lateks.
d) Pinset, Gunting.
e) Larutan povidone-iodine untuk disinfektan luka.
f) Tisu pembersih bebas alkohol.

\section{Analisis Perbandingan Tata Letak Awal dan Tata Letak Usulan}

Menurut Yamit (2011) prinsip dasar dalam menyusun tata letak fasilitas pabrik yaitu jarak perpindahan barang paling minimum, waktu perpindahan bahan dari satu proses ke proses lainnya dalam satu industri yang minimum. Berdasarkan hasil pengolahan data diatas maka dipilihlah tata letak usulan. Tata letak usulan dipilih karena memiliki jarak perpindahan bahan lebih minimum dibandingkan dengan tata letak awal.

Jarak perpindahan aliran bahan pada tata letak usulan diketahui sebesar 26,495 meter sedangkan pada tata letak awal sebesar 42,945 meter. Sehingga perencanaan tata letak usulan dapat meminimalkan jarak perpindahan aliran bahan sebesar 16,45 meter. Apabila dilihat dari segi perhitungan waktu perpindahan aliran bahan dalam 1 hari (4 kali proses produksi) pada tata letak awal sebesar 626,14 detik sedangkan pada tata letak usulan sebesar 326,24 detik. Sehingga tata letak usulan mampu menghemat waktu perpindahan bahan sebesar 299,9 detik. Hal ini menunjukkan perancangan menggunakan Algoritma Blocplan mampu menghasilkan jarak yang optimal.

Selain itu, proses produksi yang lebih singkat, mengurangi risiko bagi kesehatan dan keselamatan kerja bagi karyawan dan mengurangi faktor yang bisa merugikan dan mempengaruhi kualitas dari bahan baku ataupun produk jadi. Tata Letak yang baik akan lebih menekankan untuk meminimalkan aktivitas-aktivitas pemindahan bahan pada saat proses produksi berlangsung. Hal ini akan mendapatkan penghematan biaya perpindahan bahan, pendayagunaan yang lebih baik akan pemakaian mesin, tenaga kerja atau fasilitas produksi, mengurangi work in process, mengurangi kemacetan lainnya (Wignjosoebroto, 2009). 


\section{KESIMPULAN}

Berdasarkan hasil penelitian yang dilakukan di UMKM Duta Fruit Chips dapat disimpulkan sebagai berikut.

1. Kondisi tata letak pada fasilitas produksi keripik nangka belum memiliki perencanaan tata letak yang sistematis. Terdapat empat departemen yang belum berurutan sesuai dengan alur proses produksinya yaitu pada bagian penyimpanan bahan baku (departemen A) dan pengupasan (departemen B), bagian pengupasan (departemen B) dan bagian pencucian dan perendaman (departemen C), bagian pembekuan (departemen D) dan bagian penggorengan (departemen E). Hal tersebut menyebabkan terjadinya jarak perpindahan aliran bahan yang cukup panjang dan berpotensi terhadap kecelakaan kerja bagi karyawan.

2. Tata letak usulan yang dipilih berdasarkan hasil pengolahan Blocplan yang memiliki nilai Rscore mendekati 1 . Tata letak yang dipilih yaitu tata letak layout 1. Tata letak tersebut mampu meminimalkan jarak dan waktu proses perpindahan aliran bahan. Selain mampu meminimalkan jarak dan waktu perpindahan aliran bahan tata letak usulan juga meminimalkan tingkat kecelakaan kerja dengan memperpendek jarak antar departemen penyebab risiko kecelakaan kerja, secara tidak langsung juga dapat meningkatkan output produksi.

3. Berdasarkan hasil analisis keselamatan dan kesehatan kerja yang dilakukan didapatkan sejumlah temuan hazard. Temuan hazard yang tingkat risiko tergolong ekstrim yaitu pada jalur lintas departemen perendaman dan pembekuan sedangkan yang tingkat risiko tinggi terdapat pada departemen pengupasan dan penggorengan. Sumber hazard yang didapatkan berupa tidak menggunakan alat pelindung diri, lantai licin.Temuan hazard berupa lantai licin dipengaruhi oleh kondisi tata letak antar departemen yang tidak sistematis sehingga menyebabkan jarak tempuh perpindahan aliran bahan terlalu jauh.

\section{SARAN}

Adapun saran yang dihasilkan berdasarkan hasil penelitian adalah sebagai berikut.

1. UMKM Duta Fruit Chips disarankan melakukan perbaikan kondisi tata letak fasilitas produksi yaitu disesuaikan dengan urutan proses produksi agar dapat meminimalkan jarak perpindahan bahan, waktu proses pemindahan bahan dan tingkat kecelakaan kerja.

2. UMKM Duta Fruit Chips disarankan lebih meningkatkan dan memperhatikan kondisi kesehatan dan keselamatan kerja di lingkungan produksi dengan cara melakukan pengadaan alat pelindung diri dan memberikan himbauan kepada karyawan untuk menggunakannya. Selain itu secara berkala melakukan monitoring dan evaluasi terkait riwayat kecelakaan kerja ataupun kondisi kesehatan para karyawan.

3. Tata letak usulan pada penelitan ini menghasilkan jarak, waktu proses pemindahan bahan yang lebih minimal karena kondisi tata letak sudah sesuai dengan urutan proses produksi. Kesesuaian kondisi tata letak dengan urutan proses produksi dapat meminimalkan jarak antar departemen yang dapat menimbulkan risiko kecelakaan kerja dibandingkan dengan tata letak awal. UMKM Duta Fruit Chips disarankan dapat menjadikan penelitian ini sebagai bahan pertimbangan untuk perbaikan tata letak.

\section{DAFTAR PUSTAKA}

Handoko, A. 2013. Perancangan tata letak fasilitas produksi pada UD AHENG Sugar Donut's di Tarakan. J. Ilmiah. $1(2): 1-21$. 
Heragu, S. 2016. Facilities Design, 4th Ed. CRC Press, New York.

Karthick, M. dan P. Saravanan. 2014. Hazard Identification and Risk Assessment in Casting. International Journal of Scientific Engineering and Technology Research. 3(7) : 1260-1262.

Kurnia, D. 2018. Pelaku UMKM Jatim Didorong Terapkan Pelaksanaan K3. Republika Online. https://www.republika .co.id/berita/ekonomi/makro/18/01/12/p2 fkiv335-pelaku-umkm-jatim-didorongterapkan pelaksanaan-k3 diakses pada, 12 Januari 2019.

Mubarok, F. 2017. Jumlah UMKM Meningkat, Omzet Tumbuh Pesat. Radar Malang Online. https://radarmalang.id/ jumlah-umkm-meningkat-omzet-tumbuh -pesat/ diakses pada 27 November 2018.

Purnomo, H. 2004. Perencanaan dan Perancangan Fasilitas. Graha Ilmu, Yogyakarta.

Susetyo, J., R. A. Simanjuntak, dan J. M. Ramos. 2010. Perancangan ulang tata letak fasiltas produksi dengan pendekatan group tecnology dan algoritma blocplan untuk meminimasi ongkos material handling. Jurnal Teknologi. 3(1) :

Reksohadiprodho, S. 2008. Manajemen Produksi. BPEE, Yogyakarta.
Rohlita, M. 2018. Pabrik Terbakar dan Rugi Rp500-an juta, Anton Hanya Bisa Pasrah. Radar Lampung Online. https://radarlampunggrup.com/2018/10/2 0/pabrik-terbakar-dan-rugi-rp500-anjuta-anton-hanya-bisa-pasrah/ diakses pada 20 Oktober 2018

Siregar, R. M., D. Sukatendel, dan U. Tarigan. 2013. Perancangan ulang tataletak fasilitas produksi dengan menerapkan algoritma blocplan dan algoritma corelap pada PT . XYZ. J. Teknik Industri USU. 1(1) : 35-44.

UNSW Health and Safety. 2008. Risk Management Program. University of New South Wales, Canberra. http://www.ohs.unsw.edu.au/ohsriskmana gement diakses pada 27 Desember 2018.

Wignjosoebroto, S. 2009. Tata Letak Pabrik Dan Pemindahan Bahan. Guna Widya, Surabaya.

Yamit, Z. 2011. Manajemen Produksi dan Operasi. EKONOSIA, Yogyakarta.

Yuliantoro, R. B., M. H. Hasyim, dan K. P. Negara. 2014. Optimasi site layout menggunakan multi-objectives function pada proyek pembangunan Gedung Kuliah Terpadu Tahap III Politeknik Negeri Malang. J. Mahasiswa Jurusan Teknik Sipil. 3(1) : 1-8. 